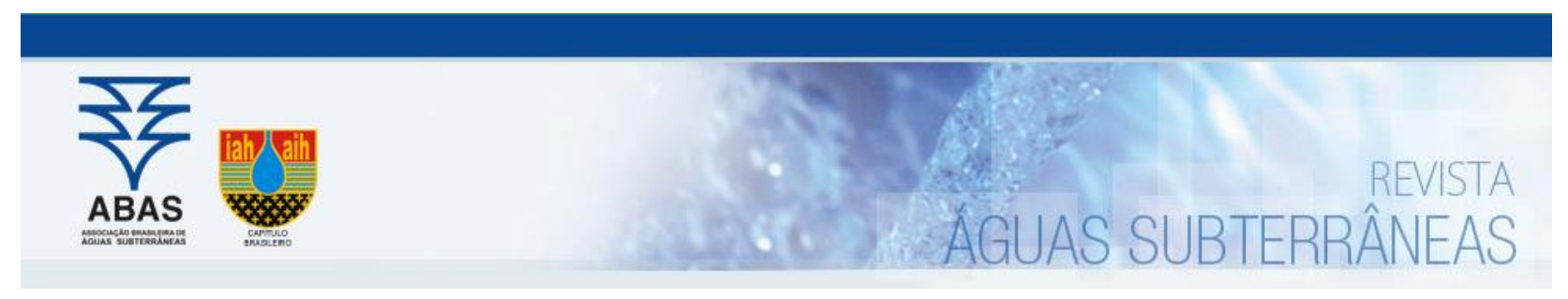

Artigos

\title{
Statistical comparison between the adjustment equations of the water retention curve in sanitary landfills coverage soil
}

\section{Comparação estatística entre as equações de ajuste da curva de retenção de água em solo de cobertura de aterro sanitário}

\author{
Alexandre de Souza Júnior ${ }^{1}$; Bruna Silveira Lira ${ }^{1}$; Henrique Antônio Oliveira Araújoํㄱ Jeovanesa Régis Carvalho ${ }^{1}$; Maria Natália \\ de Melo Sousa1; Pabllo da Silva Araujo루 Renan Ítalo Leite Gurjão1; William de Paiva1 ${ }^{1 凶}$
}

1 Universidade Federal de Campina Grande (UFCG), Campina Grande, PB

$\checkmark$ alexandrejr5@hotmail.com, brunaslira@gmail.com, henrique.zamoura@gmail.com, jeovanesaregis@gmail.com, natalia.melo.sousa@gmail.com, pabllosa@gmail.com, renan.ilg@gmail.com, wpaiva461@gmail.com

Keywords:
Soil;
Suction;
Filter paper technique;
Water retention curve;
Adjustment equations.
Palavras-chave:
Solo;
Sucção;
Técnica do papel de filtro;
Curva de retenção de água;
Equações de ajuste.
Revisão por pares.
Recebido em: 14/09/2021.
Aprovado em: $20 / 12 / 2021$.

\begin{abstract}
Residual soils result from chemical weathering, so their characteristics depend on environmental factors, in addition to origin, topography, drainage and geological age. In the unsaturated condition, the behavior of soils is conditioned by suction, which refers to the state of the soil under reduced pressure. The aim of this study is to compare the water retention curve fitting equations in the study of tropical unsaturated soils through the filter paper technique and the analytical analysis of the data obtained in this test. By performing the analysis of the statistical evaluation parameters used in this study and the proximity of its values to the necessary boundary conditions defined for the equation to explain the soil suctioning behavior of the soil as it loses moisture naturally to the environment, it was verified that the Van Genuchten equation appeared to be the most suitable.
\end{abstract}

Resumo

Os solos residuais resultam do intemperismo químico, logo suas características dependem de fatores ambientais, além de origem, topografia, drenagem e idade geológica. Na condição não saturada, o comportamento dos solos é condicionado pela succão, que se refere ao estado do solo sob pressão reduzida. 0 objetivo deste estudo é comparar as equações de ajuste da curva de retenção de água no estudo de solos tropicais insaturados através da técnica do papel filtro e a análise analítica dos dados obtidos neste ensaio. Ao realizar a análise dos parâmetros de avaliação estatística utilizados neste estudo e a proximidade de seus valores às condições de contorno necessárias definidas para a equação para explicar o comportamento de sucção do solo à medida que ele perde umidade naturalmente para o meio ambiente, foi verificou que a equação de Van Genuchten parecia ser a mais adequada.

DOI: http:/doi.org/10.14295/ras.v35i3.30073

\section{INTRODUCTION}

Residual soils naturally found on all continents, especially in the tropical climate area, and formed in areas close to its parent rock, are due to constant erosion by physical and chemical processes. Das and Sivakugan (2016) stated that the effect of weathering varies widely depending on the climatic conditions in that area. The characteristics of the residual soil depend on its parent rock and vary along the depth towards the weathered rock.

The unsaturated or partially saturated condition, when associated with changes in the structure of the residual soils generates changes in the geotechnical and mechanical behavior of these soils, which are not well explained by the usual geotechnical parameters, thus making the description of the soils less consistent with reality (FREDLUND; RAHARDJO, 1993).

Lateritic soil is a highly weathered tropical soil. The water pre- sent in the soil is responsible for solubilizing the ions adhered to the constituent materials of the soil and promotes the dissolution of the occluded gases in the pores. The presence of water in unsaturated soils, changes in moisture, due to climate change, modify properties such as capillarity and soil suction, interfering with their behavior (CAMAPUM DE CARVALHO et al., 2015).

According to Fredlund and Rahardjo (1993), to distinguish saturated soils from unsaturated soils, it is necessary to know their characteristics regarding the environment in which the soil is located and its behavior in engineering constructions. Unsaturated soils can be divided into three phases: liquid (I), gaseous (g) and solid (s). The gas phase consists of dry air and water vapor, the liquid phase consists of liquid water and dissolved dry air, and the solid phase is composed of soil grains (SÁNCHEZ et al., 2016; ABED; SOŁOWSKI, 2017; ZHENG et al., 2020). 
Fredlund and Morgenstern (1977) postulated the fourth phase for unsaturated soil, in addition to the air, water and solid phases. This additional phase, called the contractile skin or air-water interface, acts as an elastic membrane pulling soil particles through surface tension and influencing the soil's mechanical behavior (RAHARDJO; KIM; SATYANAGA, 2019).

The need for contractile skin to be recognized as a fourth phase can be visualized through the observation of volume changes that can occur, for example, due to the shrinkage imposed by the air-water interface during the drying of a soil (FREDLUND, 2016).

Due to the capillary effect on the soils, a movement of the water rise occurs, where it is raised above the level of the water table, against the action of gravity. The difference between air (atmospheric) and water pressures $\left(u_{a r}-u_{w}\right)$ is called soil suction. The suction present in unsaturated soils is always negative (CAMAPUM DE CARVALHO et al., 2015).

In general, the total suction of a soil ( $\left.\Psi_{\text {Total }}\right)$ is usually divided into two components: the matric suction ( $\Psi$ Mat $)$ and the osmotic suction $\left(\Psi_{0 s m}\right)$. Therefore, the total suction is given by Equation (1):

$\Psi_{\text {Total }}=\Psi_{\text {Mat }}+\Psi_{\text {Osm }}$

The main methods of obtaining suction consider the direct or indirect interaction with soil, the direct interaction being that which measures the energy of the water in the pores, and the indirect interaction is the one in which are obtained parameters that can be related to the suction of the soil through a calibration.

One of the main methods of obtaining suction indirectly is by means of the filter paper technique. Filter paper is considered an indirect method of suction evaluation, since calibration equations are used to determine the suction values, where moisture is transferred from the unsaturated material to the dry filter paper, after an equilibrium period (KUCHIISHI et al., 2019).

Basically, there are two techniques using filter paper to assess suction: non-contact and with contact. In the non-contact technique, the transfer of moisture from the soil to the paper takes place in the vapor phase above the specimen, since the filter paper is suspended above the sample. In the contact technique, the filter papers are placed in direct contact with the soil sample. Consequently, adsorption forces control the transfer of moisture from the soil to the paper. In both techniques, equilibrium suction and equilibrium soil moisture are determined by the amount of water adsorbed by the papers and by the paper's calibration curve. (GARAKANI et al., 2018).

One way to evaluate the suction of a soil is by means of the water retention curve, which consists of the graphical presentation of the relation between the matric or total suction and the moisture (gravimetric or volumetric) or degree of saturation. By means of this curve, parameters describing the behavior of the unsaturated soil can be estimated. These parameters can be verified by means of the retention curves of each type of soil (ARAUJO, 2017).

The retention curves are calibrated by equations of the filter paper itself and by curve fitting equations.

On the other hand, the curve fitting equations relate intrinsic parameters such as residual volumetric moisture $\left(\theta_{\text {Res }}\right)$, volumetric moisture saturation ( $\theta_{\text {sat }}$ ), matric suction ( $\Psi_{\text {Mat }}$ ), as well as parameters dependent on soil type (CAMAPUM DE CARVALHO et al., 2015). Normal volumetric moisture $\left(\theta_{\text {Nor }}\right)$ and soil volumetric moisture $(\theta)$ can be determined by Equation (2).

$\theta_{\text {Nor }}=\frac{\theta-\theta_{\text {Res }}}{\theta_{\text {sat }}-\theta_{\text {Res }}}$

Being, $\theta_{\text {Nor }}=$ normalized volumetric moisture; $\theta=$ soil volumet ric moisture; $\theta_{\text {Res }}=$ residual volumetric moisture; $\theta_{\text {sat }}=$ volumetric moisture saturation.

That being said, the aim of this study is to compare the water retention curve fitting equations in the study of tropical unsaturated soils through the filter paper technique and the analytical analysis of the data obtained in this test.

\section{MATERIALS AND METHODS}

\subsection{Soil characterization}

For the physical characterization, the tests presented in Table 1 were carried out in order to identify the type of soil and its properties.

Table 1 - Soil characterization tests

\begin{tabular}{cc}
\hline Test & \multicolumn{1}{c}{ Norm } \\
\hline $\begin{array}{c}\text { Soil samples - Preparation for compactation and } \\
\text { characterization tests } \\
\text { Grain size analysis }\end{array}$ & ABNT (2016a) \\
Liquid limit & ABNT (2016e) \\
Plasticity limit & ABNT (2016c) \\
Soil water permeability & ABNT (2016d) \\
Specific gravity of the Soil & ABNT (2000) \\
Compaction test & ABNT (2016b) \\
& ABNT (2016f)
\end{tabular}




\subsection{Preparation of test specimens}

In order to perform the filter paper test, specimens were molded using the Marshall compactor. It used cylindrical molds with $0.10 \mathrm{~m}$ of height and $0.10 \mathrm{~m}$ of diameter, accor-

ding to DNIT (1995). The process consisted of mechanically striking soil samples inserted into the mold to the normal Proctor energy at its optimum moisture and maximum dry apparent density (Figure 2).

Then, using a press, metal rings $0.07 \mathrm{~m}$ in diameter and 0.02 $\mathrm{m}$ in height were screwed onto the specimen (S) in order to extract samples with the same dimensions.
All samples were compacted at the optimum moisture content of the soil, identified as $12 \%$, determined by the Proctor compaction test. After the preparation of the samples, the moisture content of the specimen was varied to values of $\pm 2 \%$ and $\pm 4 \%$ of the optimum soil compaction moisture.

The process of increase and decrease of the moisture content of the samples was based on the method proposed by Scariot (2018), where the samples were submitted to the water spraying process or drying through the use of a dryer until test specimens were obtained, approximately, in the defined moistures (Figure 3 and Figure 4).

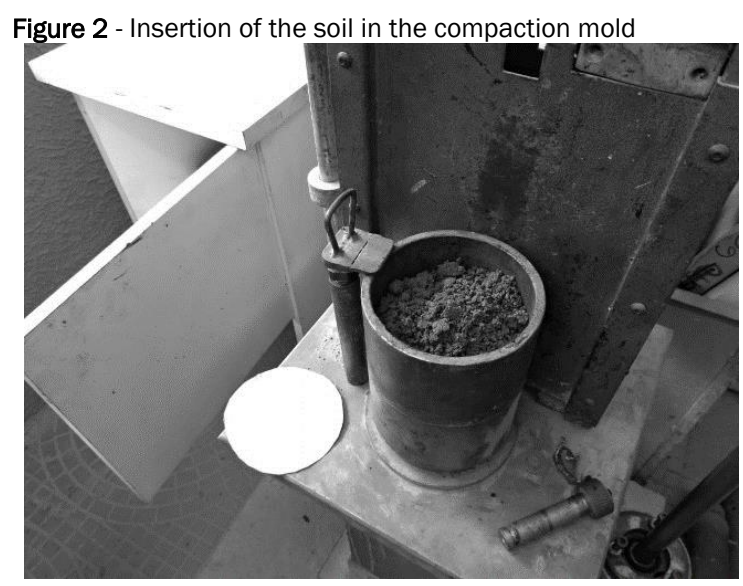

Figure 3 - Sprinkling water to the sample

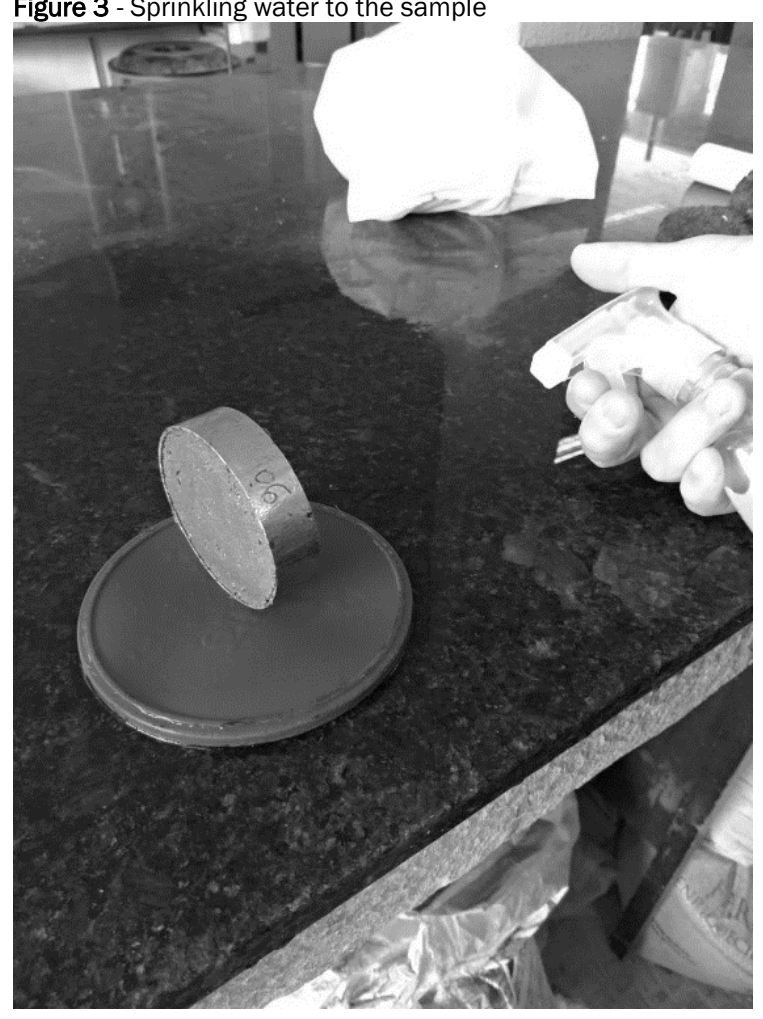




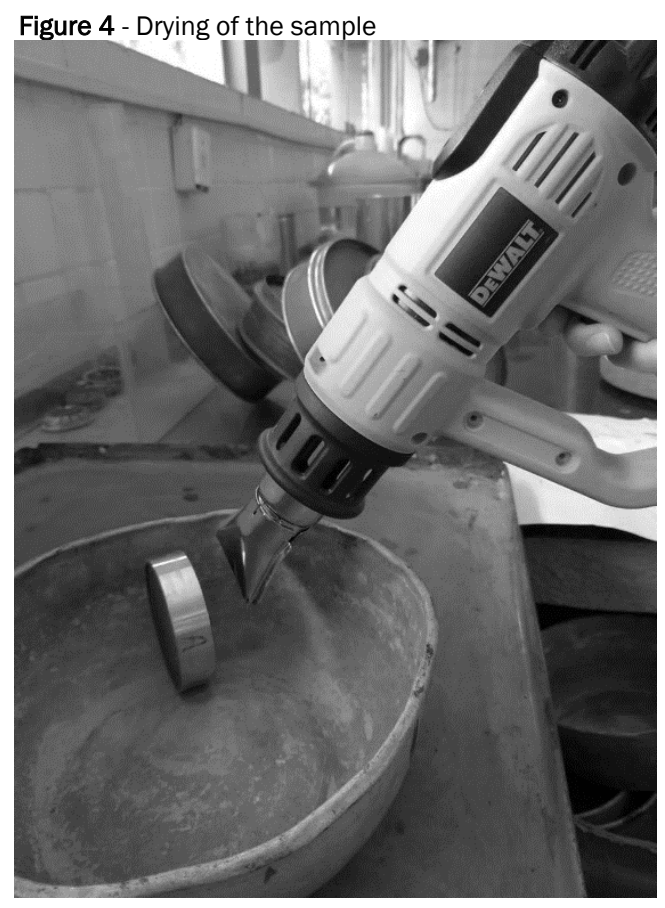

\subsection{Paper Filter Method}

After the molding procedure of the specimens with the increase and decrease of their moisture contents, two filter paper (Whatman $\mathrm{N}^{\circ}$. 42) of $0.07 \mathrm{~m}$ in diameter were placed. The first was placed in direct contact with the soil of the mold in order to obtain the matric suction; while the second paper, was placed on a plastic screen that separated it from direct contact with the soil, in order to obtain the total suction of the soil. Thereafter, the ensemble was wrapped with several layers of
PVC film and a layer of foil in order to avoid moisture loss and interference from the external environment. Each specimen was labeled and remained for 15 (fifteen) days at rest inside a thermal box for the purpose of thermodynamic equilibrium (exchange of moisture and temperature equilibrium).

After the resting time of 15 (fifteen) days had elapsed, then these papers were placed in capsules and taken to the oven for 24 hours at a temperature of $100 \pm 5^{\circ} \mathrm{C}$. (Figure 5).

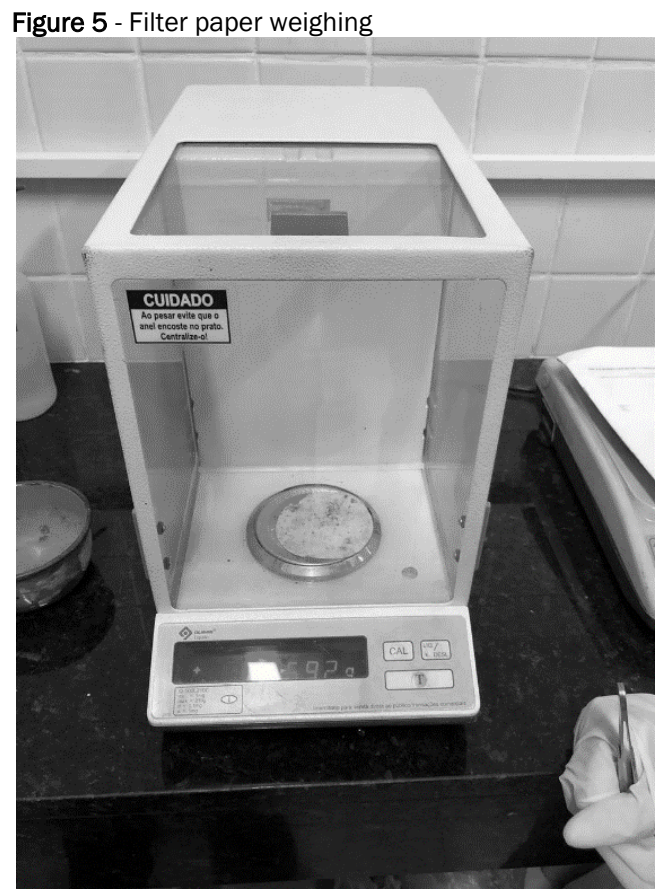


With the moisture content of the filter papers, the experimental data was calibrated in the equations of Chandler et al. (1992) and ASTM (2010), Table 2.

\subsection{Curve Adjustment Equations}

The equations proposed by Gardner (1956), Van Genuchten (1980) and Fredlund and Xing (1994) were used to adjust soil water retention curves obtained by calibration of the filter paper, since according to Gerscovich and Sayão (2002), represent the best adjustments for Brazilian soils.

\subsection{Statistical analysis}

The software STATISTICA 12.0 was used for the treatment of the experimental data in order to adjust the parameters of the equation to the experimental data. From the Gauss-Newton interactive process, it was established a maximum number of interactions of 100 , a convergence criterion of $10-6$ and a significance level $\alpha=5.0 \%$, obtaining the values of the parameters of the analyzed equations.

Table 2 - Filter paper calibration equations

\begin{tabular}{cccc}
\hline Reference & Type of suction & Equations & Requirements \\
\hline \multirow{2}{*}{ Chandler et al. (1992) } & \multirow{2}{*}{ Not defined } & $\Psi=10^{(4.84-0.0622 \times \text { Wpf }}$ & $W_{\text {pf }} \leq 47 \%$ \\
& & $\Psi=10^{(6.05-2.48 \times \text { LogWpf }}$ & $W_{\text {pf }}>47 \%$ \\
D5298 (ASTM, 2010) & Not defined & $\Psi=10(5.327-0.0779 \times$ Wpf $)$ & $W_{\text {pf }}<45.3$ \\
& & $\Psi=10(2.413-0.0135 \times$ Wpf $)$ & $W_{\text {pf }}>45.3$ \\
\hline
\end{tabular}

Source: Adapted from Araujo (2017).

\section{RESULTS AND DISCUSSION}

This research was developed in the city of Campina Grande$\mathrm{PB}$, located in the Agreste region of Paraíba and inserted in the Brazilian Semiarid Region, where it has an average temperature of $22.7^{\circ} \mathrm{C}$, annual evaporation of $1417.4 \mathrm{~mm}$ and average annual rainfall of $802.7 \mathrm{~mm} /$ year, which represents conditions typical of semi-arid zones and tropical latitudes (AESA, 2017).

The experimental field of this research is the sanitary landfill located at Fazenda Logradouro II in the municipality of Campina Grande-PB, located at kilometer 10 of the PB-138 that connects the city of Campina Grande to the district of Catole de Boa Vista.

The landfill has been in operation since the month of July 2015 occupying a total area of 80 ha, with 39,384 ha destined for the construction of municipal solid waste cells. Designed to initially receive 350 tons of waste per day, for a useful life of 25 years, it now receives 500 tons of waste/day from the municipality of Campina Grande as well as contributions from other municipalities.

As material for covering the waste, a clayey soil from the bed of an empty reservoir (earth dam) in the landfill region is used. The collection of the soil to carry out the tests proceeded in compliance with the ABNT NBR 9604/2016 standard, where the samples were packed in plastic bags and taken to carry out the tests as deformed samples.

In the laboratory, the soil was spread out in the open air for prior drying until near hygroscopic moisture, following the procedures described in ABNT NBR 6457/2016. After drying, the clods of soil were dismantled, taking care not to break the grains. Then, the soil was homogenized and quartered to obtain a representative sample in sufficient quantity to carry out the characterization tests.

\subsection{Physical characterization of the soil}

Figure 6 shows the particle size distribution curve of the studied soil. The analyzed soil is classified as a silty sand (SM), according to the D2487 (ASTM, 2011), which governs the classification of the Unified Soil Classification System (USCS), and has a particle size distribution of $1.0 \%$ gravel, $7.0 \%$ coarse sand, $27.0 \%$ medium sand; $48.0 \%$ fine sand, $7.0 \%$ silt and $10.0 \%$ clay. It has a coefficient of non-uniformity (CNU) in the order of 37 and curvature coefficient (CC) in the order of 3 , being characterized as a non-uniform and well graded soil. The grain size curve showed predominance of the sand fraction, $82 \%$, to the detriment of fine fractions, silt $7.25 \%$ and clay $9.75 \%$. 
Figure 6 - Granulometric soil curve

CLAY SILT

SAND

GRAVEL

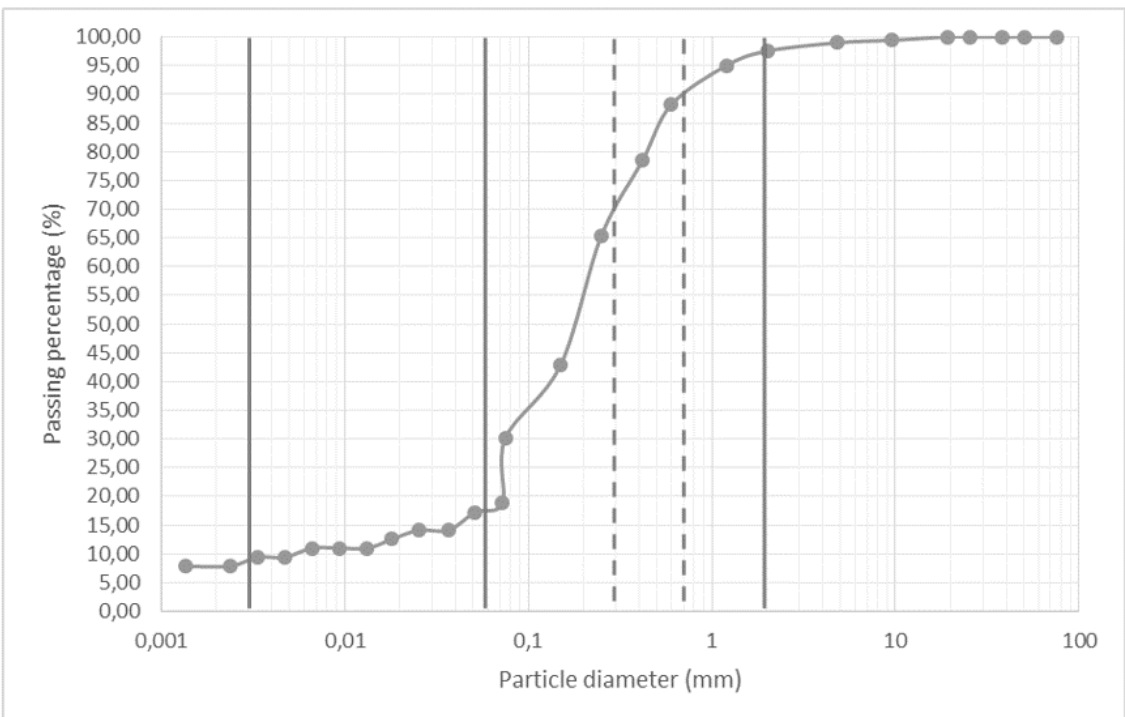

The Table 3 presents the soil physical indexes. It behaves as a non-liquid (NL) and non-plastic (NP) material, corroborated by the low hygroscopic moisture content of $0.80 \%$, typical of sand predominant soils with low water retention. According to Sá and Silva (2010), in the semi-arid environment, where the municipality of Campina Grande-PB and its district of Catolé de
Boa Vista are located, climate and geology play a major role in the formation of soils. In this region, the geology is quite variable with predominance of crystalline rocks, followed by sedimentary areas, covered by sandy or clayey materials and of small thickness.

Table 3 - Atterberg Limits and Specific Gravity of Soil

\begin{tabular}{cccc}
$\begin{array}{c}\text { Specific Gravity of Soil } \\
\left(\mathrm{g} / \mathrm{cm}^{3}\right)\end{array}$ & $\begin{array}{c}\text { Liquid Limit } \\
(\%)\end{array}$ & $\begin{array}{c}\text { Plasticity Limit } \\
(\%)\end{array}$ & $\begin{array}{c}\text { Plasticity Index } \\
(\%)\end{array}$ \\
\hline 2.68 & $\mathrm{NL}$ & $\mathrm{NP}$ & $<4$ \\
\hline
\end{tabular}

Figure 7 shows the soil saturation curves for the Proctor compaction test. From the compaction test, an optimum moisture content of $12.0 \%$ was obtained, lying between $80 \%$ and $90 \%$ of soil saturation, as observed by Pinto (2006). It has a maxi- mum specific apparent dry weight of $18.20 \mathrm{kN} / \mathrm{m}^{3}$, which according to Dantas Neto et al. (2013), soils with predominance of sand in their composition, when compared with clayey soils, present higher values of specific maximum dry weight.

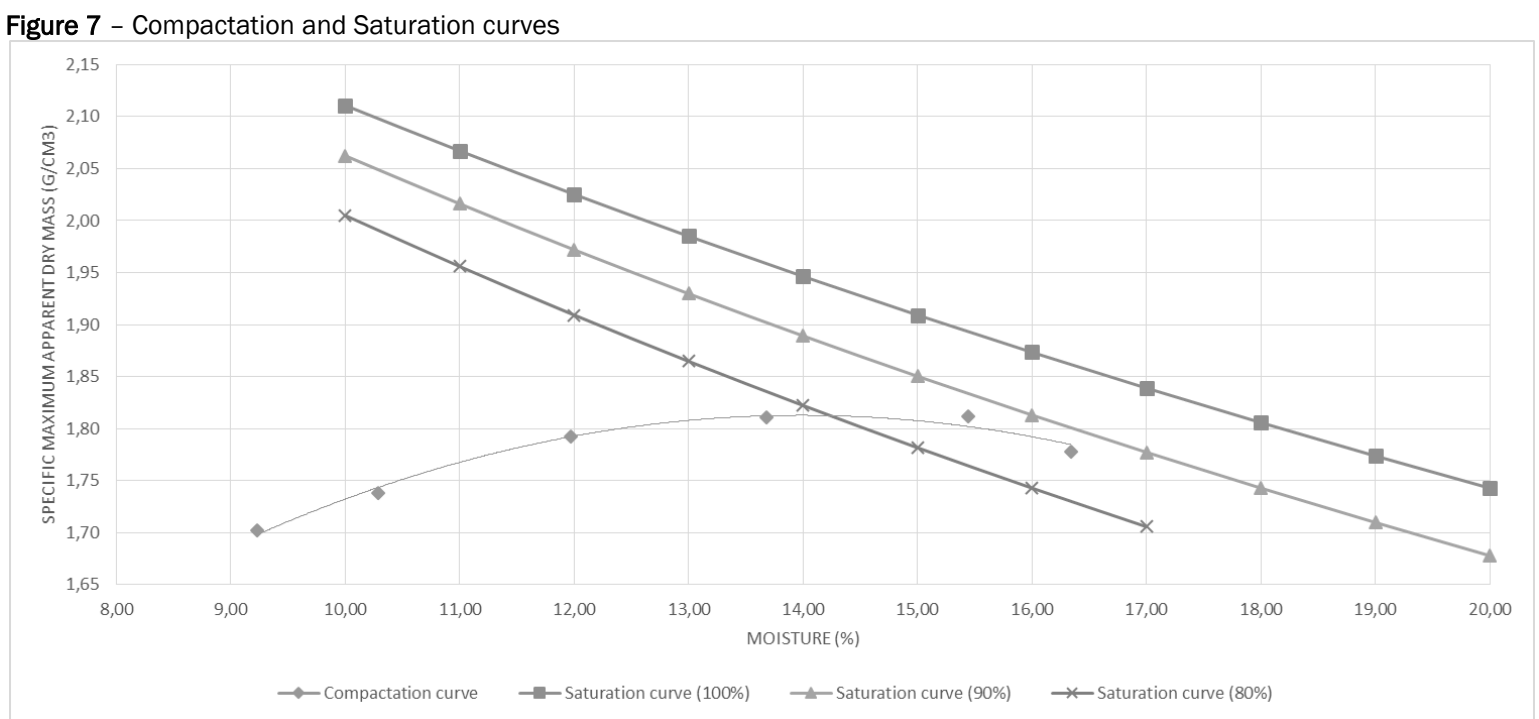

Its saturated permeability to water is of the order of $1.0 \times 10^{-6}$ $\mathrm{m} . \mathrm{s}^{-1}$. According to Pinto (2006), soils with this permeability are characterized as silty soils; as for Knappett and Craig
(2016), such permeability is typical of very fine sands. From the value of soil water permeability, one can accept the statement by Ramos et al. (2016), that soils with coarse texture 
have a lower water retention capacity due to the small percentage of fine materials (silt and clay) in their composition. The analyzed soil presents $82 \%$ of sand in its composition.

\subsection{Water retention curve in soil}

With the calibration of the parameters contained in the adjust- ment equations of Chandler et al. (1992) and ASTM (2010), the experimental data obtained in the suction test by the filter paper method was adjusted, finding a semi-logarithmic graphical relation between the soils matric suctions $(\Psi)$ by their respective volumetric moisture content $(\theta)$, (Figure 8).

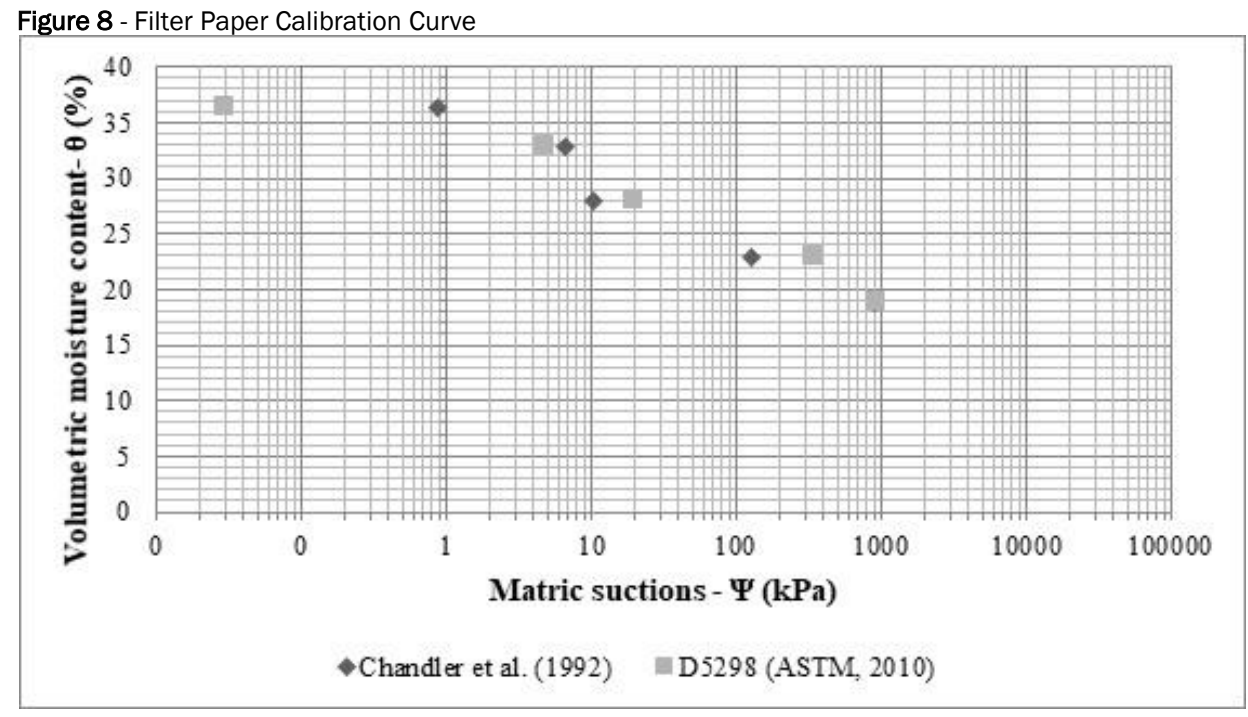

It is observed in Figure 13, values close to matric suction between the two forms of calibration of the filter paper, ranging from about $1.0 \mathrm{kPa}$ to $1000.0 \mathrm{kPa}$. As expected, there is an increase in soil suction as the volumetric moisture of the material tends to decrease.

\subsection{Curve Adjustment and Statistical Analysis}

After the treatment of the experimental data in the Statistica 12.0 software, the following statistical parameters can be obtained for the analysis of the curve adjustment, Table 4 . It is worth noting that the order of analysis initially follows the determination coefficient $\left(R^{2}\right)$, the Mean Square Error (MSE), the standard error and finally the Akaike information criterion (AIC).

It is observed through Table 4 that for the Chandler et al. (1992) method, the adjustments of the experimental data to the soil characteristic curve proposed by Gardner (1956) and
Van Genuchten (1980) present determination coefficients $\left(R^{2}\right)$ closer to the unit, the latter presents the lowest values of MSE and Standard Error. For the adjustment proposed by Gardner (1956), the calculated AIC was the largest negative value, 40.86, among those analyzed.

Figure 9 shows the Van Genuchten (1980) curve ajustment obtained from the analysis of the experimental data determined by the Chandler et al. (1992) method. From the curve, it is observed a maximum value of $40 \%$ volumetric moisture, a residual matric suction ( $\Psi_{\text {Res }}$ ) of $50 \mathrm{MPa}$, residual volumetric moisture $\left(\theta_{\text {Res }}\right)$ of $15 \%$, and the formation of frontier zones (beginning of the curve), transition (sloping part of the curve) and residual (after point 1), as specified by Fredlund et al. (1996). According to Fredlund and Xing (1994), the behavior of the curve corroborates that of granular soils, because they have macropores that prevent the retention of water and the easy loss of moisture.

\begin{tabular}{|c|c|c|c|c|c|}
\hline Methods & Curve Adjustments & $\mathbf{R}^{2}$ & $\begin{array}{c}\text { MSE } \\
\left(\times 10^{-4}\right)\end{array}$ & $\begin{array}{l}\text { Standard error } \\
\left(\times 10^{-3}\right)\end{array}$ & AIC \\
\hline \multirow{3}{*}{$\begin{array}{l}\text { Chandler et al. } \\
\qquad(1992)\end{array}$} & Gardner (1956) & 0.97 & 112.62 & 3.29 & -40.86 \\
\hline & Van Genuchten (1980) & 0.97 & 111.80 & 2.90 & -38.94 \\
\hline & Fredlund and Xing (1994) & 0.96 & 124.28 & 3.29 & -37.88 \\
\hline \multirow{3}{*}{$\begin{array}{c}\text { D5298 } \\
\text { (ASTM, 2010) }\end{array}$} & Gardner (1956) & 0.95 & 143.27 & 3.02 & -38.46 \\
\hline & Van Genuchten (1980) & 0.97 & 110.70 & 1.09 & -39.04 \\
\hline & Fredlund and Xing (1994) & 0.90 & 196.68 & 5.05 & -33.29 \\
\hline
\end{tabular}


Figure 9 - Adjustment of soil water retention curve of the Chandler et al. (1992) method

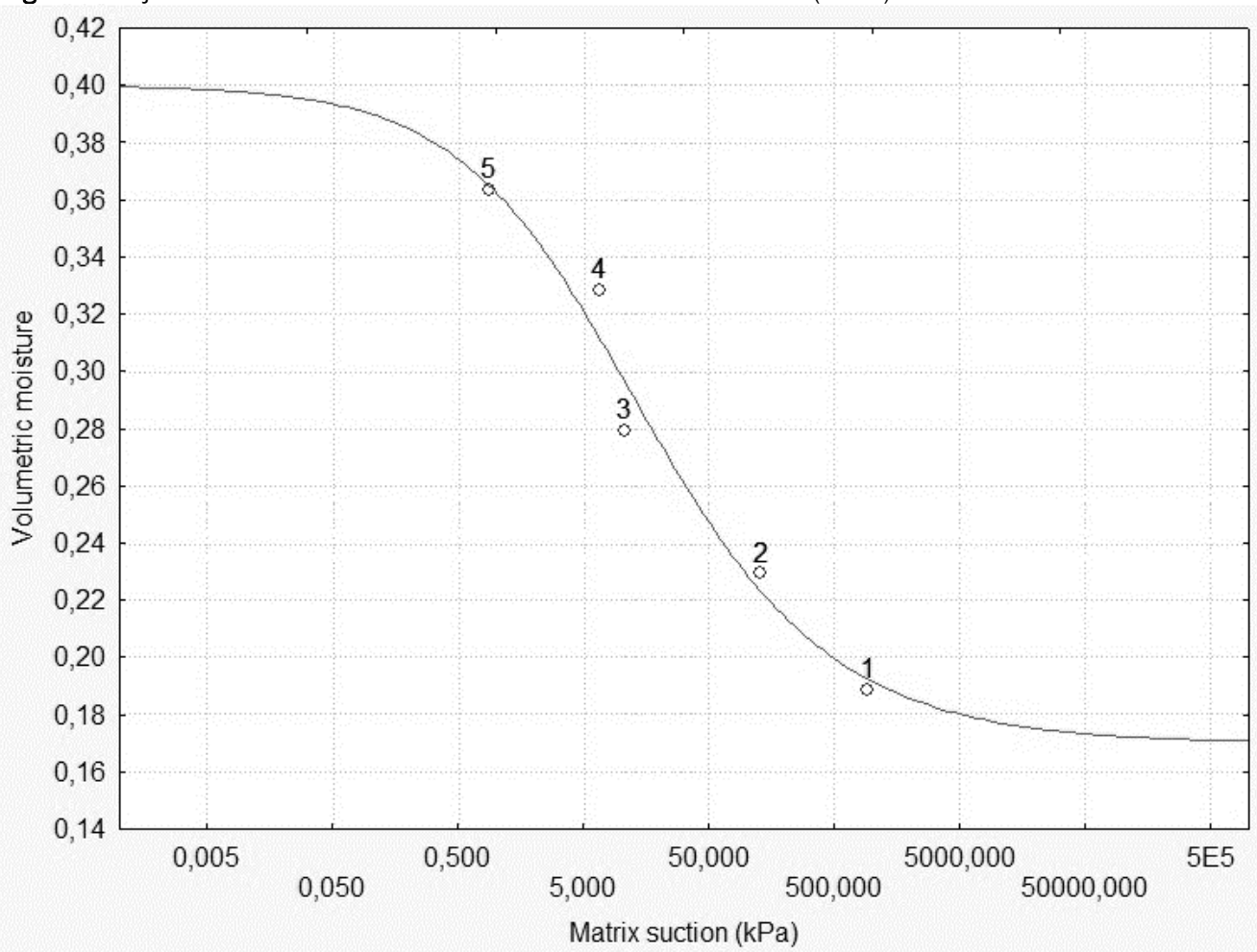

Still from Table 4, it can be observed that for the D5298 (ASTM, 2010) method, the Van Genuchten (1980) curve ad-

of MSE and standard error, as well as the most negative value justment presented statistic parameters more significant than the other adjustment equations. The adjustment in question of AIC among the others. In Figure 10, the experimental data found by the D5298 (ASTM, 2010) method adjusted to the Van Genuchten (1980) equation are exposed. has a determination coefficient closer to the unit, lower values

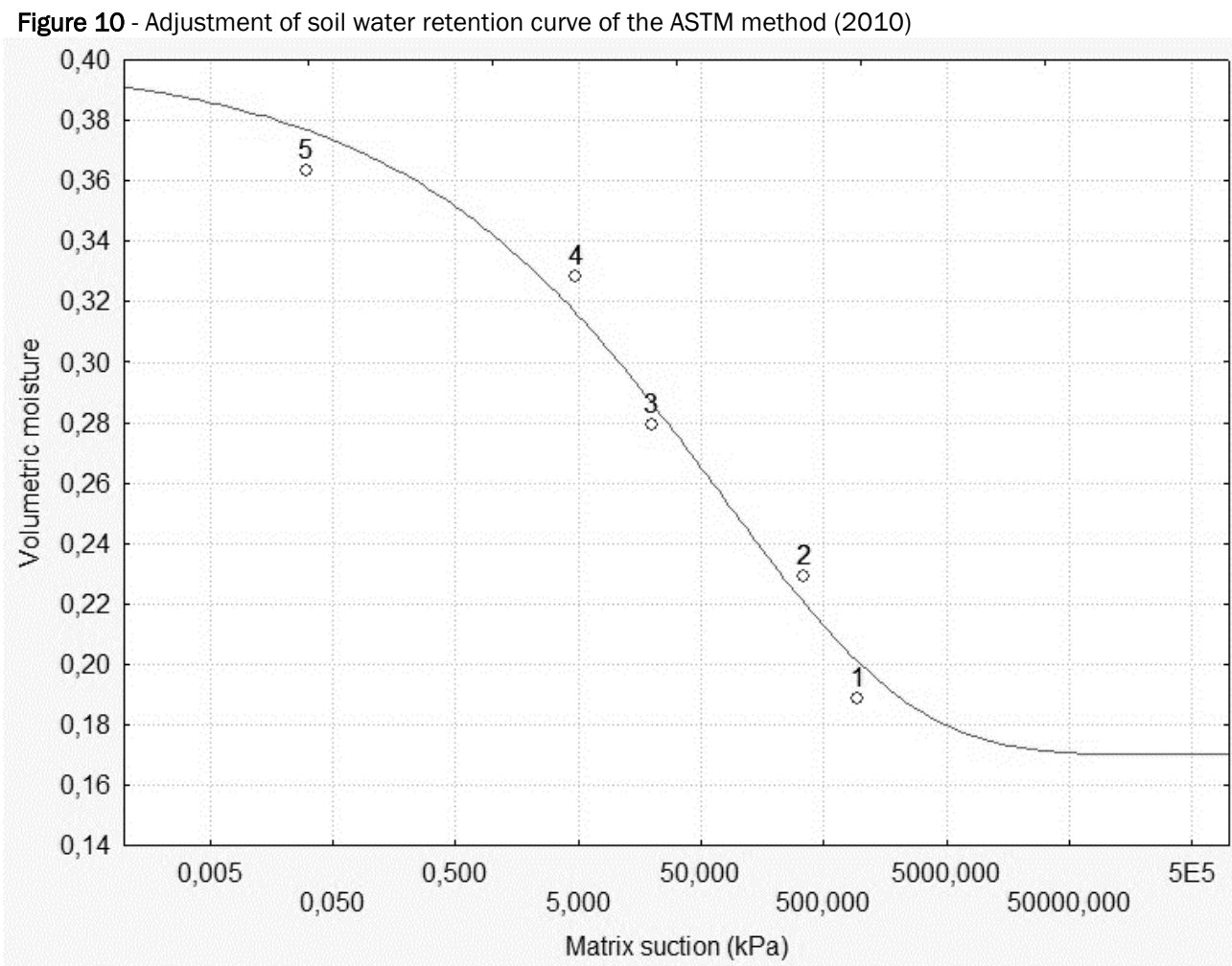


The curve of Figure 10 shows a behavior similar to that of the Chandler et al. (1992) method. The highest volumetric moisture $(\theta)$ recorded by the data was approximately $39 \%$, with residual matric suction $\left(\Psi_{\text {Res }}\right)$ and residual volumetric moisture $\left(\theta_{\text {Res }}\right)$ equal to the previous method.

\section{CONCLUSIONS}

It is concluded, from the study, that:

- The Van Genuchten equation is the most adequate to explain the behavior of the experimental data, with a significance level of $5.0 \%$. This assertion could be verified by the proximity of its values to the necessary boundary conditions defined for this equation to explain the matric suction behavior of this soil as it loses moisture naturally to the environment;

- Among the calibration methods, the use of the Chandler equation is recommended. This equation presented the statistical parameters results closest to the limit values defined in this study, in addition to, being the most used equation to calibrate the filter paper and determine the soil characteristic curve;

- $\quad$ For the definition of the adjustment equation that best explains the behavior of experimental data, it is verified that the larger the number of statistical parameters used for analysis of the experimental data in comparison to the estimates, the more significant the results.

\section{ACKNOWLEDGENMENTS}

To the Pavement Engineering Laboratory (LEP), to the Laboratory of Environmental Geotechnics (LGA) and to the Postgraduate Program in Civil and Environmental Engineering (PPGECA) of the Federal University of Campina Grande (UFCG), Campus I; to the Postgraduate Program in Environmental Science and Technology (PPCGTA) of the State University of Paraíba (UEPB), Campus I.

\section{REFERENCES}

ABED, A. A.; SOŁOWSKI, W, T. A study on how to couple the thermo-hydromechanical behavior of unsaturated soils: Physical equations, numerical implementation and examples. Computers and Geotechnics, v. 92, p. 132-155, 2017. https://doi.org/10.1016/j.compgeo.2017.07.021

ABNT. NBR 6457: Soil sample: preparation for compaction tests and characterization tests. Rio de Janeiro: ABNT, 2016a. $8 p$.

ABNT. NBR 6458: Gravel gravel retained in the opening sieve $4.8 \mathrm{~mm}$ - Determination of specific mass, apparent specific mass and water absorption. Rio de Janeiro, RJ : - ABNT, 2016b. $10 p$.

ABNT. NBR 6459: Determination of the liquidity limit. Rio de Janeiro, RJ: ABNT, 2016c. 5p.

ABNT. NBR 7180: Determination of the plasticity limit -. ABNT, Rio de Janeiro, RJ: ABNT, 2016d. 3p.
ABNT. NBR 7181: Particle size analysis. Rio de Janeiro, RJ: ABNT, 2016e. 12p.

ABNT. NBR 7182: Compaction - Procedure. Rio de Janeiro, RJ: ABNT, 2016f. 9p.

ABNT. NBR 14545: Soil: determination of the permeability coefficient of clayey soils at variable load. Rio de Janeiro, RJ: ABNT, 2000. 12p.

AESA - AGÊNCIA EXECUTIVA DE GESTÃO DAS ÁGUAS DO ESTADO DA PARAÍBA. Meteorologia, monitoramento. AESA, Fev. 2017. Disponivel em http://site2.aesa.pb.gov.br/aesa/medicaoPluviometrica.do? metodo=listarClimatologiasMensais.

ALONSO, E. E.; GENS, A.; HIGHT, D.W. Special problems soils General Report, Proc. 9th European Conference on Soil Mechanics and Foundation Engineering, Dublin, v. 3, p.10871146, 1987.

ARAUJO, P. S. Analysis of the performance of a compacted soil used in the covering layer of a sanitary landfill. Dissertation, Post-graduation in Civil and Environmental Engineering. Federal University of Campina Grande, Campina Grande, 2017. 138p.

ASTM. Standard test method for measurement of soil potential (suction) using filter paper - D5298. ASTM International, West Conshohocken, PA, USA, 2010. 6p.

ASTM. Standard practice for classification of soils for engineering purposes (Unified Soil Classification System) D2487. ASTM International, West Conshohocken, PA, USA, 2011. 12p.

BRUTSAERT, W. Some methods of calculating unsaturated permeability. Transactions of ASABE, v.10, n.3, p.400-404, 1967. https://doi.org/10.13031/2013.39683

CAMAPUM DE CARVALHO, J.; GITIRANA JR., G. F. N.; MACHADO, S. L.; MASCARENHA, M. M. A.; SILVA FILHO, F. C. Unsaturated soils in the geotechnical context. 1st ed. Brazilian Association of Soil Mechanics and Geotechnical Engineering, São Paulo, 2015. 759p.

CHANDLER, R. J.; CRILLEY, M. S.; MONTGOMERY-SMITH, G. A low-cost method of assessing clay desiccation for low-rise buildings. In: Proceedings of the Institution of Civil Engineers - Civil Engeneering. Thomas Telford-ICE Virtual Library, p.8289, 1992. https://doi.org/10.1680/icien.1992.18771

DAS, B. M.; SIVAKUGAN, N. Fundamentals of geotechnical engineering. Cengage Learning, 5th edition, 2016.

DANTAS NETO, J. A.; CATEANO NETTO, E. A.; NASCIMENTO JÚNIOR, L. F.; DELMOND, J. G. Study of soils with different textures in optimal compaction humidity. Proc. 7th Academic Semester of the University of Goiás Santa Helna de Goiás campus. v.1, n. 1, 2013. 4p.

DNIT. Hot bituminous mixtures - Marshall test - ME-043. DNIT, Rio de Janeiro, RJ, Brazil, 1995. 11p.

FREDLUND, D. G. State Variables in Saturated-Unsaturated Soil Mechanics. Soils and Rocks, São Paulo, v. 39, n. 1, p. 317, 2016. https://doi.org/10.28927/SR.391003 
FREDLUND, D. G.; MORGENSTERN, N. R.Stress state variables for unsaturated soils. Journal of The Geotechnical Engineering Division, v.103, n.5, p.447-465, 1977. https://doi.org/10.1061/AJGEB6.0000423

FREDLUND, D. G.; RAHARDJO, H. Soil mechanics for unsaturated soils. 1.ed. John Willey \& Sons, Danvers/Massachusetts/USA, 1993. https://doi.org/10.1002/9780470172759

FREDLUND, D. G.; XING, A. Equations for the soil water characteristic curve. Canadian Geotechnical Journal, v.31, n.4, p.521-532, 1994. https://doi.org/10.1139/t94-061

FREDLUND, D. G.; XING, A.; FREDLUND, M. D.; BARBOUR, S. L. The relationship of the unsaturated soil shear strengh to the soil-water characteristic curve. Canadian Geotechnical Journal, v. 33, n.3, p.440-448, 1996. https://doi.org/10.1139/t96-065

GARDNER, W. R. Representation of soil aggregate size distribution by a logarithmicnormal distribution. Soil Science Society of America Proceedings, v. 20, n.2, p.151-153, 1956. https://doi.org/10.2136/sssaj1956.03615995002000020 $\underline{003 x}$

GERSCOVICH, D. M. S.; SAYÃO, A. S. F. J. Evaluation of the soilwater characteristiccurves equations for soils from Brazil. In: INTERNATIONAL CONFERENCE ON UNSATURATED SOILS, 3. 2002. Proceedings [...]. Recife: v.1, p.293-300, 2002.

GITIRANA JR., G. F. N.; FREDLUND, D. G. Soil-water characteristic curve equation with independent parameters Journal of Geotechnical and Geoenvironmental Engineering, ASCE, v. 130, n. 2, p.209-212, 2004. https://doi.org/10.1061/(ASCE)10900241(2004)130:2(209)

GARAKANI, A A.; HAERI, S. M.; CHERATI, D. Y.; GIVI, F. A.; TADI, M. K.; HASHEMI, A. H.; QAHREMANI, F. Effect of road salts on the hydro-mechanical behavior of unsaturated collapsible soils. Transportation Geotechnics, 2018. https://doi.org/10.1016/j.trgeo.2018.09.005

KNAPPETT, J. A.; CRAIG, R. F. Craig mechanical soil. Rio de Janeiro: LTC, 2016. 419p.

KUCHIISHI, A. K.; ANTÃO, C. C. S.; VASCONCELOS, K.; PIRES, J.; ARAÚJO, O. M. O.; BERNUCCI, L. L. B.; LOPES, R. T. Investigation of the role of matrix suction in the curing mechanism of stabilized mixes with foamed bitumen. Road materials and paving project, 1-25, 2019 https://doi.org/10.1080/14680629.2019.1589558
MARINHO, F. A. M. Measurement of suction in soils. Proc. 3rd Brazilian Symposium on Unsaturated Soils, v.2, p.373-397, 1997.

MCKEE, C. R.; BUMB, A. C. Flow-testing coalbed methane production wells in the presence of water and gas. Society of Petroleum Engineers Formation Evaluation, v.2, n. 4, p.599608, 1987. https://doi.org/10.2118/14447-PA

PINTO, C. S. Basic course of soil mechanics in 16 classes. 3. ed. Oficina de textos, São Paulo, 2006. 367p.

RAMOS, T. B.; GONÇALVES, M. C.; MARTINS, J. C.; PEREIRA, L. S. Water retention characteristics in soil for use in crop irrigation. National Institute of Agrarian and Veterinary Research, Oeiras, 2016. 76p.

SÁ, I. B. \& SILVA, P. C. G. Brazilian semi-arid: research development and innovation. Embrapa Semiárido, Petrolina, 2010. 402p.

SCARIOT, K. A. DE L.. Parametric study of the shear strength of a low support bearing soil. Dissertation, Post-graduation in Civil and Environmental Engineering. Federal University of Campina Grande, Campina Grande, 2018.

SILVA, T. A Evaluation of the influence of suction and degree of weathering on the lateral buoyancy coefficient (kO) of residual soils. Dissertation, Post-graduation in Civil Engineering. Pontifical Catholic University of Rio de Janeiro, Rio de Janeiro, 2017. 105p.

VAN GENUCHTEN, M. T. A closed-form equation for predicting the hydraulic conductivity of unsaturated soils. Soil Science Society of America Journal, v.44, n.5, p.892-898, 1980. https://doi.org/10.2136/sssaj1980.03615995004400050 $\underline{002 x}$

RAHARDJO, H., KIM, Y.; SATYANAGA, A. Role of unsaturated soil mechanics in geotechnical engineering. Geo-Engineering v. 10, n. 8, 2019. https://doi.org/10.1186/s40703-0190104-8

SÁNCHEZ, M.; GENS, A.; VILLAR, M. V.; OLIVELLA, S. Fully Coupled Double Porosity Thermo-Hydro-Mechanical Formulation for Unsaturated Soils. International Journal of Geomechanics, v. 16, n. 6, 2016. https://doi.org/10.1061/(ASCE)GM.1943-5622.0000728

ZHENG, F., SHAO, S., WANG, J.,; SHAO, S. Experimental Study of the Mechanical Behavior of Natural Loess Based on Suction-Controlled True Triaxial Tests. KSCE Journal of Civil Engineering, 2020.

https://doi.org/10.1007/s12205-020-1386-2 